\title{
Pensonomonoor
}

2017, vol. 78, 111-123

http://dx.doi.org/10.12657/denbio.078.011

\author{
Lushuang Gao, Chunyu Zhang, Xiuhai Zhao, Li Zhang
}

\section{The direct and indirect effect of fire on radial growth of Pinus koraiensis trees in a northern temperate forest of China}

\author{
Received: 4 May 2017; Accepted: 6 June 2017
}

\begin{abstract}
The long-term effects of fire on the radial growth of Korean pines (Pinus koraiensis) in Changbai Mountain is poorly understood. In order to quantify the impact of fire on the radial growth of Korean pines, we measured ring widths and developed two tree-ring chronologies from 21 burned Korean pine trees that were damaged by fire in 1857 as well as 30 control trees in the Changbai Mountain Nature Reserve, China. As expected, the growth rates of the burned trees were slower than those of the control trees in the first five years following the fire. However, beginning six years after the fire, the growth of the burned trees increased considerably, and this period of increased growth lasted 13 years, with moderate growth occurring throughout the 1866 to 1871 period. A difference in growth rates between burned and control tress was also observed for the 20 years since temperatures began markedly increasing in 1980. Burned trees tended to respond negatively to monthly minimum temperature, precipitation, and vapor pressure deficits (VPD), whereas the positive relationship between those factors and radial growth of control trees became stronger. In addition, the significantly negative effect of competition on radial growth was only observed among burned trees. These results demonstrated that the negative and direct effect of damage to physiological plant processes by fire only affected the years shortly after a fire occurred and then became obscured by its indirect effects, such as differential responses to climate and competition, which did persist for a long time. The indirect effect on radial growth over time could be explained by the variability in the relative strength of climatic responses and competition caused by fire.
\end{abstract}

Keywords: burned trees, growth pattern, competition, climate, Korean pine

Addresses: L. Gao, C. Zhang, X. Zhao, Key Laboratory for Forest Resources \& Ecosystem Processes of Beijing, Beijing Forestry University, Beijing, 100083, P. R. China, e-mail: gaolushuang@bjfu.edu.cn L. Zhang, Beijing LinMiao Eco-Environment Technology Co.,Ltd

\section{Introduction}

Fire is an important factor in conifer forests as it alters radial growth of trees (Van Sickle \& Hickman, 1959), forest composition (Clements, 1910), and stand dynamics (Souza, 2007). However, there is a lack of agreement concerning the effects of fire on radial growth patterns. Some studies have documented a decrease in growth following fires. For example, Peterson et al. (1991) determined that fire caused decreased growth of Douglas fir (Pseudotsuga menziesii) and lodgepole pine (Pinus contorta). Similarly, reduced 
growth of loblolly pines (Pinus taeda) that had been highly scorched was also observed by McInnis et al. (2004). The negative effect of fire seems to be related to damage to foliage (Peterson \& Arbaugh, 1989), cambium (Ryan \& Frandsen, 1991), and fine roots (Kummerow \& Lantz, 1983). In contrast, no changes in radial growth following fire were detected in ponderosa pine (Pinus ponderosa) (Wooldridge \& Weaver, 1965), slash pine (Pinus elliottii) (Hunt \& Simpson, 1985), Douglas fir (Ryan \& Reinhardt, 1988), and eastern white pine (Pinus strobus) (Elliott et al., 2002). The occurrence of no change in growth after a fire suggests the short-term negative effect of fire on radial growth may be offset by a positive effect resulting from the release from competition imposed by neighboring vegetation. Moreover, the radial growth of western larch (Larix occidentalis) was reduced in the first year following fire but increased over the next seven years (Ryan \& Reinhardt, 1988). Previously, Van Sickle and Hickman (1959) reported that growth of ponderosa pine in north-central Oregon increased in the second decade following a fire. A delayed tree-ring growth increase was also displayed by surviving single leaf pinyon pines (Pinus monophylla) (Py et al., 2006). It seems likely that the direct negative effects of fire on radial growth caused by injury was temporary and immediate and would thus be obscured or overridden by the indirect positive effects. The controversy over the effects of historic fire on radial growth presented above was caused by the lack of variability in the relative strength of direct and indirect effects of fire on tree growth. Therefore, an understanding of the temporal dynamics and strength of direct and indirect effects of fire must be determined to better comprehend the radial growth patterns following fires.

The variability in the relative strength of these contrasting direct and indirect effects of fire on tree growth is likely caused by the differential responses of species (González-Tagle et al., 2008) to fires (Mutch \& Swetnam, 1995; Latham \& Tappeiner, 2002) as well as to released competition for water (Skov et al., 2004) and nutrients (Riegel et al., 1992) at different ages. Radial growth of ponderosa pine trees in northern Arizona was increased in areas where crown kill was less than $60 \%$, but was decreased where crown kill exceeded $60 \%$ (Pearson et al., 1972). Prescribed fire generally appears to have positive effects on radial growth of adult giant sequoia trees (Mutch \& Swetnam, 1995). The negative effect of fire on tree growth on the windward side was greater than on leeward slope for Pinus canariensis on Tenerife, Canary Islands (Rozas et al., 2011). However, relatively few studies have quantified the temporal dynamics of direct and indirect effects of fire on radial growth of trees. Previous studies that have analyzed tree growth have relied on short-term data, generally within 10 years (Keeling \& Sala, 2012). However, the indirect positive effects of fire could be realized over much longer time periods (Hoffmann, 2002); thus, the varied competition that is released or suppressed following a fire may only be identified in medium- to long-term studies (Valor et al., 2013). Tree rings can provide a history of the sizes of immediate neighbors of a sample tree (Bakker, 2005), presenting a possibility for evaluating the effect of changing competition on growth after fire over the long term.

Additionally, the indirect positive effects of fire have seemed to moderate negative climatic effects on radial growth (Mutch \& Swetnam, 1995). The complex relationship between tree growth and climate after a fire are continuing to change at the temporal scale, especially as conditions are expected to become warmer in the future (Andreu et al., 2007). A better understanding of the possible interactions between fire and climate may be critical for interpreting long-term tree growth trends. Consequently, improved knowledge of the indirect effects of fire on growth patterns, including competition and climate over the long term, may help to identify dynamic tree growth responses under the influence of fire and facilitate improvements in forest management practices (Bergeron \& Harvey, 1997; Bergeron et al., 1999a, 1999b).

Korean pine (Pinus koraiensis Siebold \& Zucc.) is a fire-tolerant, ecologically dominant, and widely distributed conifer species in mixed broad-leaved Korean pine forests of Changbai Mountain, which is a well-known dormant volcano in northeastern China (Stone, 2010). Although fire has been recognized for several decades as a significant ecological force in mixed broad-leaved Korean pine forests (Liu \& Ge, 2003; Yang et al., 1998; Wang et al., 2003), little information is available on the effects of fire on the radial growth of Korean pines on Changbai Mountain over the long-term because few documented records of past fires exist. Some Korean pine trees with scars from previous fire damage and without any injures were located in the Changbai Mountain Nature Reserve. Tree-ring data was then collected from Korean Pines of approximately the same age within the study area; thus, these trees had grown under a common environment and common climatic conditions. This provides a rare opportunity for understanding the direct and indirect effects of fire on radial growth patterns. We tested two specific hypotheses. (1) The direct negative effects of fire on radial growth of trees are offset by indirect positive effects. (2) The indirect effects of fire on radial growth over the long term was mainly caused by modifications to climatic responses instead of trees being released from or under increasing competition. 


\section{Methods}

\section{Study site}

The two study sites (burned and control) are located in the Changbai Mountain Nature Reserve at an elevation of approximately $784 \mathrm{~m}$ above sea level (N 42²0'21.1", E 128 05'70.5"). The dominant tree species are Korean pine (Pinus koraiensis), Mongolian oak (Quercus mongolica), Manchurian ash (Fraxinus mandshurica), Amur linden (Tilia amurensis), and painted maple (Acer mono). Very few historical fire records are available for the Changbai Mountain Nature Reserve. Some Korean pine trees have visible triangles and lines indicative of fire scars on their bark. As indicated by Ge et al. (1992) and Liu et al. (1993), these scars on surviving Korean pines suggest a fire has occurred in this area in the past. Trees exhibiting these fire scars were used to identify the burned study site. The control site was established at a distance of less than $300 \mathrm{~m}$ from the burned area where a cluster of trees without injures were found. Both sites were flat (with a slope less than $5^{\circ}$ ) and had no difference in topography. The climate of the region is continental with cold winters and warm summers. The mean annual temperature was $2.7^{\circ} \mathrm{C}$. A cold arctic air mass dominates the region during the winter with an average minimum temperature in January of $-31.1^{\circ} \mathrm{C}$. The highest monthly maximum temperature was $35.8^{\circ} \mathrm{C}$ in July. The mean total annual precipitation for the region is $707 \mathrm{~mm}$.

\section{Sample collection and analysis}

Field work was conducted in 2009. Cores were taken from trees using an increment borer (Sweden Haglof, Långsele, Sweden). At least 25 trees from each site were required as expressed population signal (EPS), which expresses the fraction of the general population chronology variance, is determined by the numbers of trees (Briffa, 1984). Before sampling, the diameter at breast height (dbh) of each burned Korean pine tree in the burned site was recorded. The mean dbh of burned samples was $46.7 \pm 9 \mathrm{~cm}$, ranging from $35.7 \mathrm{~cm}$ to $55.4 \mathrm{~cm}$. In order to eliminate the influence of size, the sample trees in the control site were selected to be within this range. In order to account for competition with neighboring trees, the $\mathrm{dbh}$ of the four nearest neighboring trees and their distances to the sample tree were measured at both sites. According to the neighboring theory proposed by Gadow and Hui (1999), the effect of competition on radial growth of a sampled tree was mainly controlled by the dbh of the four nearest neighboring trees and their distances to the sample tree. Hegyi's competition index is a good indicator that reflects the competition status of each sampled tree as affected by the nearest four neighboring trees (Daniels, 1976).

For each burned tree, two cores were taken at the base (at $30 \mathrm{~cm}$ above ground), one from the side of the visible fire scar and the other one from the opposite side, as far away as possible from the scar. These were used to determine the year in which the fire occurred by counting the number of annual rings from the sampling year to the beginning of the scar (Arno \& Sneck, 1977). This technique revealed that the fire occurred in the year of 1857 . Two perpendicular increment cores of each burned and control tree were also taken at breast height (at $130 \mathrm{~cm}$ above ground), which were used to assess the differences in the growth patterns and responses to climate of the burned and control trees. In order to calculate Hegyi's competition index, one core was taken from the four nearest neighboring trees of each burned and control specimen at breast height. Because of the stand structure, both the nearest neighboring trees and the burned or control sample trees (depending on site) may also have served as the nearest neighbor to other burned or control trees. Thus, the overall number of neighboring trees is less than anticipated because this total includes previously sampled shared neighbors as well as other burned or control trees. In total, 25 burned trees (92 cores, 42 at base height and 50 at breast height), 30 control trees (60 cores), and 94 nearest neighboring trees (94 cores) were sampled.

After surfacing and cross-dating (Stokes \& Smiley, 1968), tree-ring widths of cores were measured to an accuracy of $0.01 \mathrm{~mm}$ with the Lintab5 tree-ring measurement station (Rinntech, Heidelberg, Germany). The computer program COFECHA (Grissino-Mayer, 2001) and TSAP-Win Professional, version 0.59 (Rinntech) were used to detect measurement and cross-dating errors. Missing rings were rare in the study area. A geometric method, developed by Duncan (1989), was used to estimate pith location when a partial core passed close to the pith. All samples correlated well with the mean site chronology $\left(r>0.4^{1}, n=41, p<0.05\right)$ except for sample series with line scars. Four burned samples with line scars and 10 control trees with core measurements that were poorly correlated with the mean site chronology were excluded. Another 10 control trees were sampled in 2011. Ultimately, 21 burned trees (81 cores, 41 at base height and 40 at breast height), 30 control trees (54 cores) samples, and 94 nearest neighbor trees (94 cores) were reserved for a subsequent analysis. Tree-ring chronologies were developed using the program ARSTAN (Cook, 1985). Individual

Leonelli et al. (unpublished) recommend to reject series with $\mathrm{r}<0.4$. 
ring-width measurement series were standardized by cubic spline curve standardization (CSC) with a 40year step size. This technique reduces the effect of outliers and enhances the common signal within a dataset (Cook et al., 1990).

\section{Data analysis}

We conducted $t$-tests and analyses of growth release between the burned site and the control site to determine if mean growth was significantly different in the post-burn periods. Growth release events, determined by the percentage growth change $(G)$, were calculated in yearly increments across individual tree-ring chronologies (Nowacki \& Abrams, 1997).

$$
G=\frac{\left(M_{2}-M_{1}\right)}{M_{1}} \times 100 \%
$$

where $G$ is the percentage growth change between each preceding and subsequent 5 -year means, $M_{1}$ is the preceding 5-year mean, and $M_{2}$ is the subsequent 5 -year mean. Since each percent growth change value $G$ represents a 10 -year span of ring-width data, empty cells relative to source tree-ring chronologies tend to occur at both ends. Values of $25 \%, 50 \%$, and $100 \%$ were selected to be threshold criteria for determining the growth release as minor, moderate, and severe release (Wang \& Zhao, 2011).

The temporal stability of the relationship between the growth of trees and climate in our study was assessed by a moving interval analysis using DENDROCLIM2002 (Biondi \& Waikul, 2004). For our analysis, gridded climate data (1901-2009) from the high-resolution gridded climate dataset CRUTS3.0 (Climatic Research Unit, University of East Anglia https://crudata.uea.ac.uk) were selected instead of the measured data for our area (Fig. 1), which only has reported records after 1960. We used climate data for the nearest CRU grid cell $\left(42.750^{\circ} \mathrm{N}\right.$, $128.250^{\circ} \mathrm{E}$ ), including monthly mean, maximum, and minimum temperatures as well as total monthly precipitation and vapor pressure deficit (VPD) over a 17-month window from May of the previous year (the last year of ring formation) to September of the current year (the current year of ring formation).

A moving window analysis was performed by moving a 40-year window along the standardized chronology in one-year steps. The analysis started with the window for the period 1901-1941 and ended with the window for the period 1966-2005.

The effect of competition on tree growth over the long term was assessed using Hegyi's competition index (Daniels, 1976).

$$
C I_{i}=\sum_{i=1}^{4} \frac{d b h_{j}}{d b h_{i}} \cdot \frac{1}{d i s t_{i j}}
$$

where $C I_{i}$ is the competition index for sample $i$, $d b h_{i}$ represents the dbh of the sample tree, $d b h_{i}$ is the $\mathrm{dbh}$ of the $j$ th neighbor (in $\mathrm{cm}$ ), and dist $t_{i j}$ is the distance between sample tree $i$ and neighbor $j$.

The stable distance between the four nearest neighboring trees and the sample tree combined with the historical tree diameters reconstructed from increment cores makes it is possible to infer the historic Hegyi's competition index, which can be used to analyze variation in annual growth over time (Gadow \& Hui, 1999). The length of the reconstructed dbh series is determined by the minimum age among each of the four nearest neighboring trees as a lower limit for inferring the historic competition index. Given that the minimum age at breast height of neighboring trees for the burned site was 25 years and that of the control trees was 10 years, historic competition is largely unknown over the course of the 142-year observation period. In order to compare the differential effects of

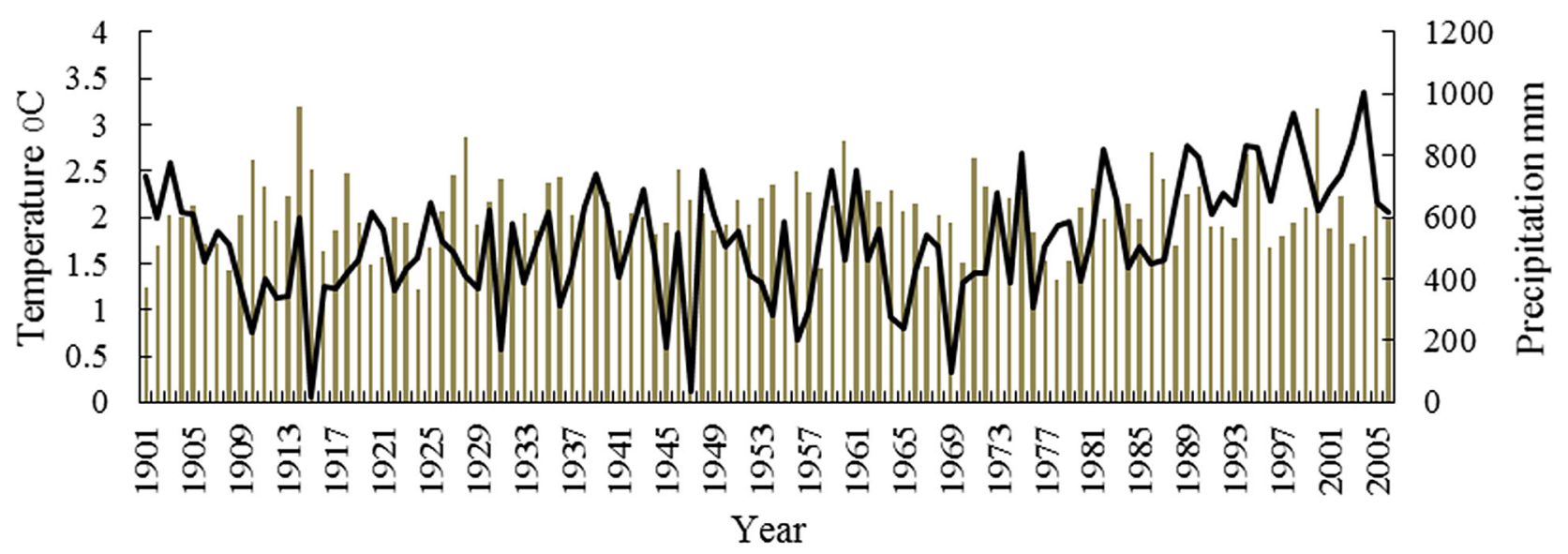

Fig. 1. Annual mean temperature (-) and annual total precipitation ( $\mathbf{m})$ at the study site from 1901 to 2009 
competition from neighboring trees between burned and control trees at a temporal scale, the relationship between competition and annual radial growth $(\mathrm{mm})$ over the past ten years was also evaluated. The program R (R Development Core Team 2010) was used to determine the relationships between the tree-ring width and Hegyi's competition index and to test the significance of these relationships at the 0.05 level.

\section{Results}

\section{Growth pattern comparison}

Although the burned and control trees were almost the same age, with similar distributions of dbh (with means around $47 \mathrm{~cm}$ ) and under common climatic conditions, greater variability in growth patterns was observed within the first 25 years following fire (i.e., 1858-82) and during the period from 1960 to 1980 (Fig. 2). Growth of burned trees decreased in the first five years immediately following fire, but increased subsequently. The considerably higher growth rate of the burned trees relative to the control trees lasted for 13 years (1866-79). During the period from 1866 to 1871 , the burned trees exhibited moderate growth release, whereas no growth release occurred among the control trees. The fluctuation in annual growth rate for burned tress was rather small in the first 25 to 65 years following fire, until a large release in 1922. Thereafter, growth was comparatively fast. A similar growth pattern was observed among the control trees. At the beginning of the 1960s, the growth pattern of burned tress changed more rapidly. During the period from 1960 to 1980, the mean annual growth rate of the burned trees was significantly higher than that of the control trees (one-tailed paired $t$-test, $t=-7.85, p<0.05)$.

As shown in Table 1, the two tree-ring chronologies from the burned and control sites with EPS values above 0.85 were considered to be reliable (Wigley et al., 1984). The two tree-ring chronologies also exhibited a similar growth pattern as individual growth series (Fig. 3). As the chronology of the burned site had a higher signal-to-noise ratio (SNR) and mean correlation between trees (RBAR) relative
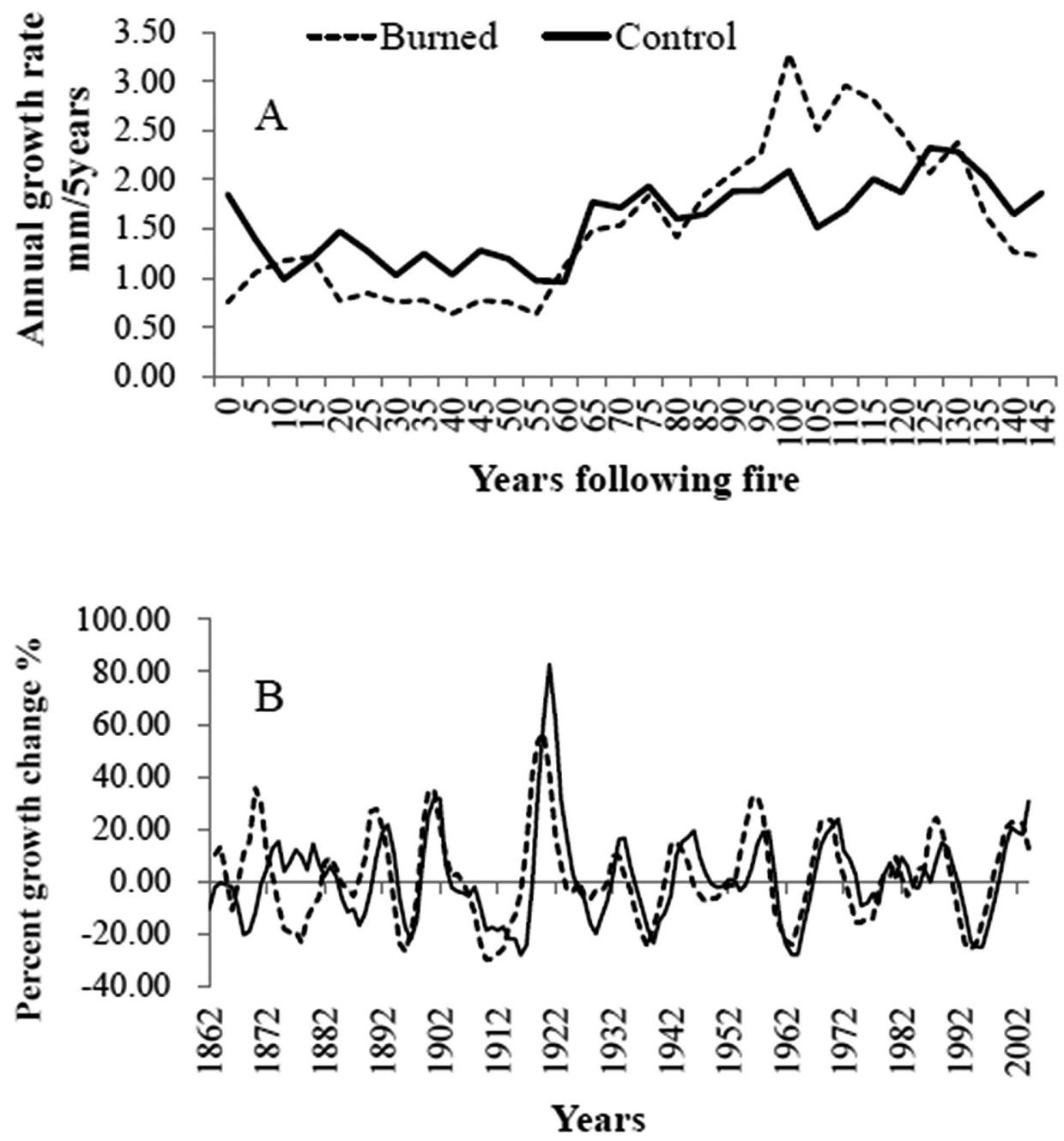

Fig. 2. Growth pattern of burned and control Korean pine trees 
Table 1. Summary statistics of burn and control Korean pine samples and their standardized chronologies

\begin{tabular}{lcc}
\hline \multicolumn{1}{c}{ Statistics } & Burn & Control \\
\hline Number of trees (cores) & $21(40)$ & $30(54)$ \\
Mean diameter at breast height $(\mathrm{cm})$ & $46.7 \pm 9 \mathrm{~cm}$ & $47.6 \pm 6 \mathrm{~cm}$ \\
Length of chronology & AD $1859 \sim 2009$ & AD $1858 \sim 2011$ \\
Mean sensitivity (MS) & 0.19 & 0.18 \\
Signal to noise ratio (SNR) & 17.10 & 13.10 \\
Express population signal (EPS) & 0.94 & 0.93 \\
Mean correlation between trees (RBAR) & 0.62 & 0.42 \\
\hline
\end{tabular}

to the control site (Table 1), burned trees seemed to be more influenced by climate (Briffa et al., 1987).

\section{Relationships with meteorological data}

The response of the burned trees to monthly maximum temperature was similar to that of the control trees (Fig 4). The responses of both groups showed a significantly negative correlation with monthly maximum temperature in the previous growing season (PG-T $\mathrm{T}_{\max }$ ). However, the effect of monthly minimum temperature, precipitation, and VPD on radial growth significantly differed between burned and control trees. Burned trees had a significantly negative response to precipitation in the current growing season (CG-P) and VPD in the previous growing season (PG-VPD). On the contrary, the responses of control trees to CG-P and PG-VPD were both significantly positive. In contrast with the negative correlation between the monthly minimum temperature in the current growing season $\left(\mathrm{CG}-\mathrm{T}_{\min }\right)$ and growth of control trees, a significantly positive relationship was observed among burned trees.

Except for the unchanged effect of PG-VPD on radial growth of trees from the two sites, these relationships were not stable over time (Fig. 5). The negative effect of PG-T $\mathrm{T}_{\max }$ on radial growth was observed during the period from 1960 to 1990 for burned trees, but from 1990 to 2006 for control trees. The differential responses to CG-T $\mathrm{T}_{\min }$ and CG-P of burned and control trees were only found in the short term from 1960 to 1970 and from 1978 to 1990, respectively. The positive relationship between CG- $\mathrm{T}_{\min }$ and burned trees growth decreased over time during the second half of the 1990s and became non-significant after the year 2000, while the response of control trees to CG-T ${ }_{\text {min }}$ shifted from negative to positive after 1990. Additionally, the negative relationship between burned tree growth and CG-P became significant after the year 1978. In contrast with the stronger negative correlations among burned trees, the positive response of control trees to CG-P decreased after 1990.

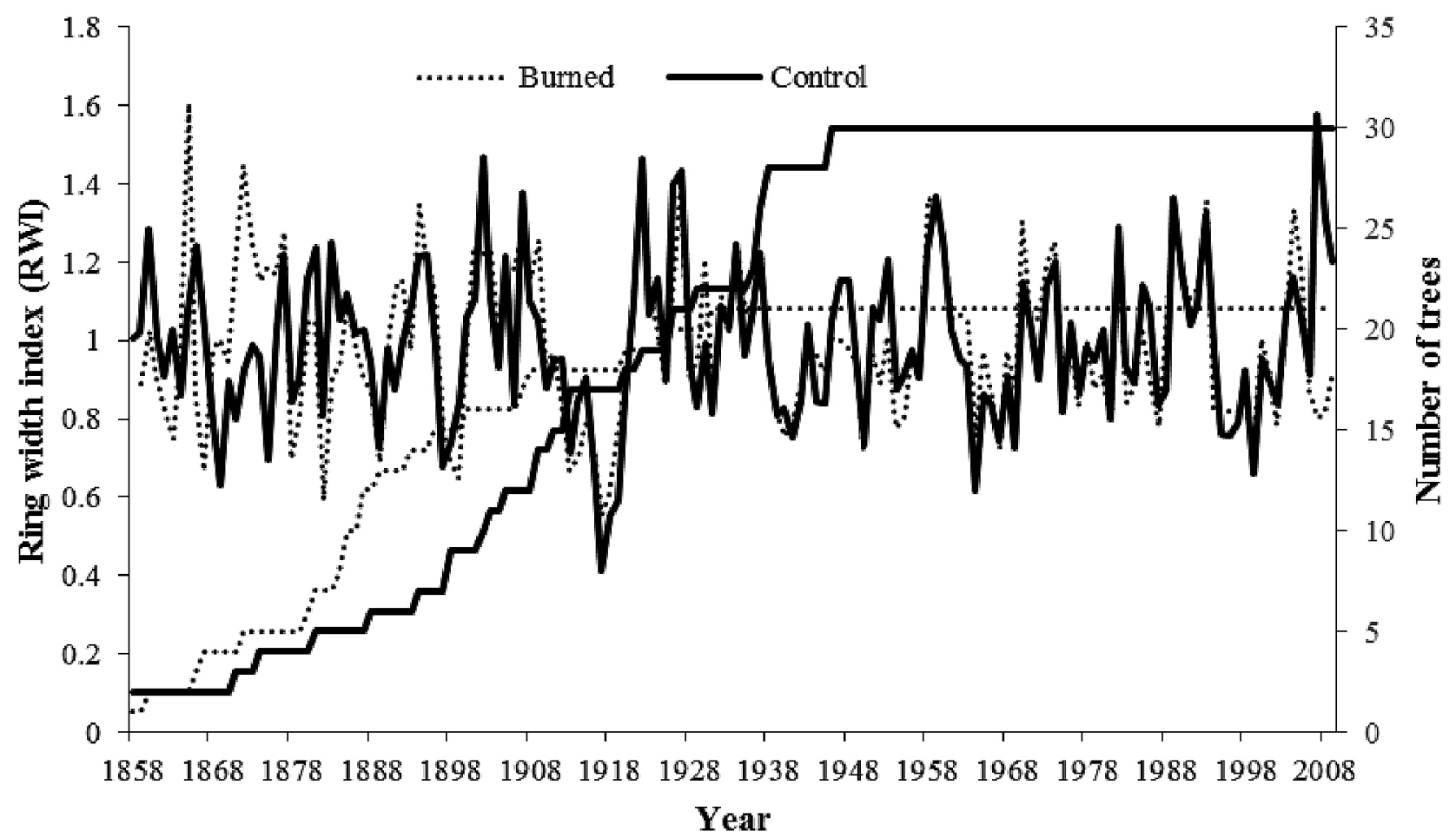

Fig. 3. Standardized tree ring chronologies for burned (1858 2009) and control (1858 2009) Korean pine trees 


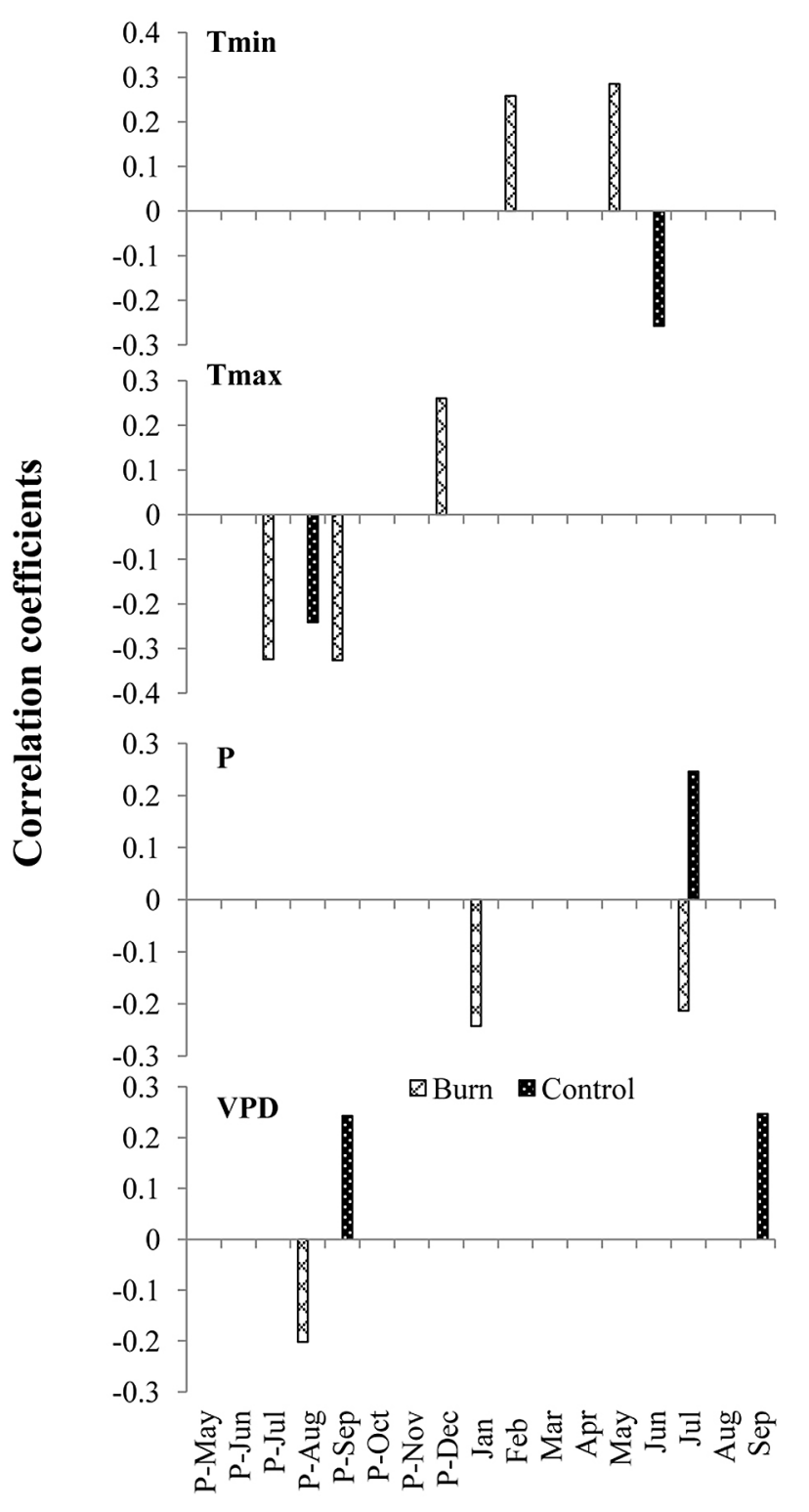

Month

Fig. 4. Correlation function results. Coefficients were computed over the period of 1901-2009 between the two standardized chronologies and the monthly minimum ( $\mathrm{T}$ min) and maximum ( $\mathrm{T} \max$ ) temperature variables, the monthly precipitation $(\mathrm{P})$ and vapour pressure deficit (VPD) variables. Only statistically significant correlation coefficient values were showed $(\mathrm{P}<0.05)$

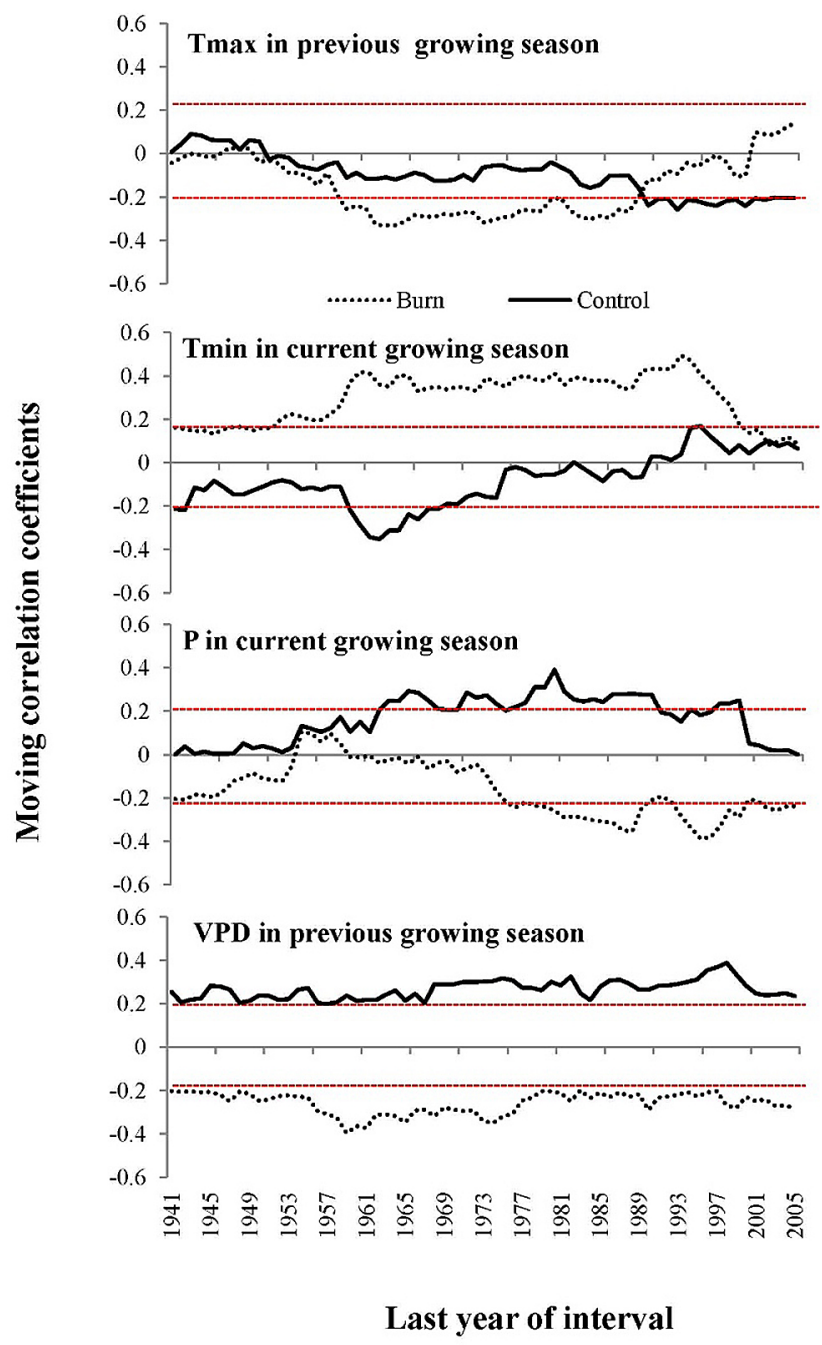

Fig. 5. Moving correlations between climate variables(Tmax, monthly maximum temperature in previous growing season; Tmin, monthly minimum temperature in current growing season, $\mathrm{P}$ monthly total precipitation in current growing season and VPD vapor pressure deficit in previous growing season) and standardized chronologies of burn trees (dotted line) and control trees (solid line). Horizontal red dotted lines indicate 95\% significance levels

Table 2. Summary statistics of neighboring trees of burn and control Korean pine samples

\begin{tabular}{lcc}
\hline \multicolumn{1}{c}{ Statistics } & Burn & Control \\
\hline Average distances between the target and neighboring trees $(\mathrm{m})$ & $2.73 \mathrm{~m}(0.5 \mathrm{~m} \sim 4.7 \mathrm{~m})$ & $2.5 \mathrm{~m}(0.8 \mathrm{~m} \sim 4.7 \mathrm{~m})$ \\
Average age at dbh of the nearest neighboring trees $(\mathrm{cm})$ & $20 \pm 4 \mathrm{~cm}$ & $14 \pm 2 \mathrm{~cm}$ \\
Average age at breast height of the nearest neighboring trees & $87(25 \sim 150)$ & $56(10 \sim 148)$ \\
Mean competition intensity & 0.86 & 0.66 \\
Correlation between competition and annual radial growth rate & $-0.5857 \mathrm{p}=0.013^{*}$ & $-0.3496 \mathrm{p}=0.242$ \\
\hline
\end{tabular}

\footnotetext{
* indicate the significantly at level 0.05 .
} 


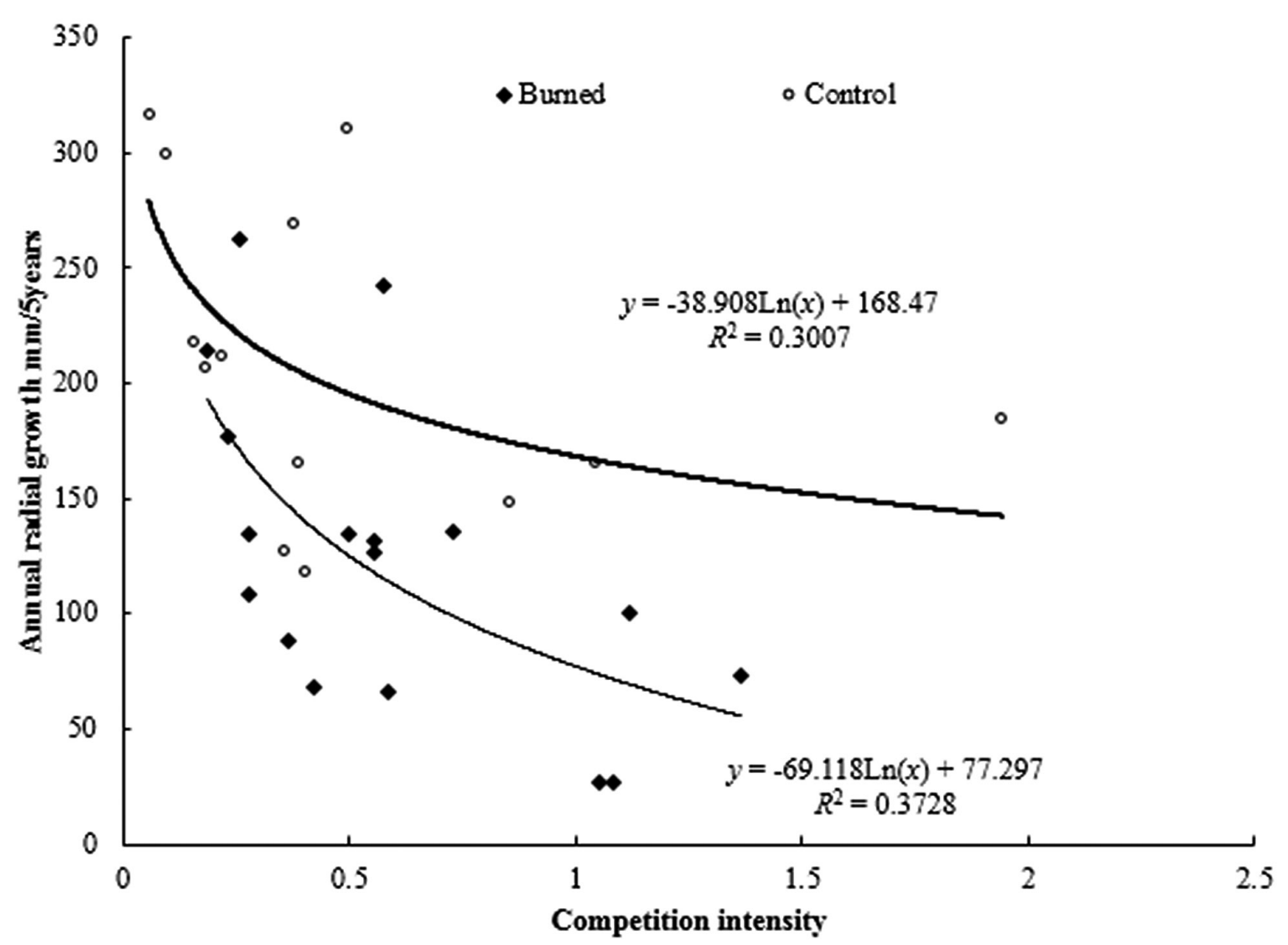

Fig. 6. The relationship between competition intensity and annual growth rate of trees
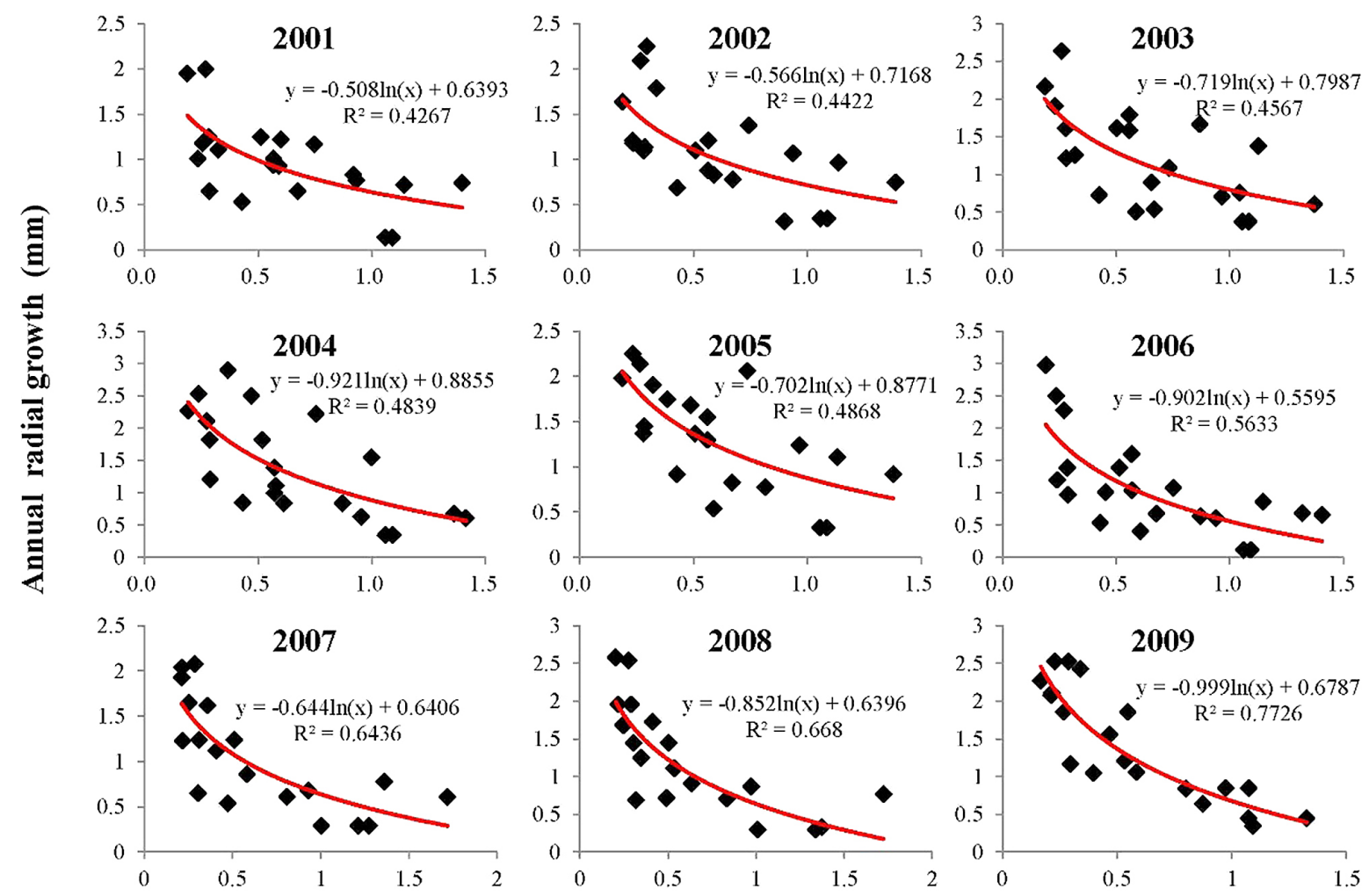

Competition intensity

Fig. 7. Historical correlation between the competition intensity and annual growth rate of burn trees during the last 10 years 


\section{Effect of recent competition}

The negative correlation between competition and annual radial growth rate was significant among the burned trees, but not significant among the control trees (Table 2, Fig. 6). This negative effect on burned trees was stable and increased during the last decade (Fig. 7). As shown in Table 2, there was no significant difference in distances from the sample tree to their nearest neighboring trees between burned and control trees. The nearest neighboring trees of burned trees were slightly older with higher dbh values than the nearest neighbors of the control trees. Burned trees seemed to be affected more severely by competition.

\section{Discussion}

Previous studies have shown that fire has a direct effect on tree growth through damaging physiological processes and an indirect effect on the control of climate responses and release from competition (Hoffman, 2002). Some studies have suggested that differential growth rates resulted from climatic responses rather than from the direct effects of fire (Mutch \& Swetnam, 1995). Our study, by focusing on a single tree species and trees of approximately the same age under common climatic conditions, was able to suggest that the direct and indirect effects of fire impacted different phases of growth.

The direct effect of fire on Korean pine trees was only observed within the first five years following fire. Similar growth patterns were reported by Van Sickle and Hickman (1959) as well as Ryan and Reinhardt (1988). Generally, fire damage results in a reduction in photosynthesis or water use efficiency, thus sharply reducing the radial growth of burned trees (Gonzalez-Rosales \& Rodriguez-Trejo, 2004). As the postfire time span increased, tree growth can recover as light and soil nutrient availability increase through reduced competition from associated trees that were damaged or killed by the fire (Certini, 2005). As a result, the growth of the surviving trees increased (Wang et al., 2007), and growth releases frequently followed the formation of fire scars (Swetnam et al., 1992). Our findings revealed that burned trees showed a continuous increasing growth pattern from the sixth year following the fire and onward for 13 years (1866-79). In this period, the moderate growth release exhibited only by burned trees was observed.

Notably, this increase in growth rate only occurs for a short time after fire, when competition for resources is less intense. Twenty years following fire, the radial growth of Korean pine trees once again decreased. This growth pattern showed that the indirect effects of fire shifted from positive to negative.
As shown by Grady and Conrad (2001), after long fire-free periods, radial growth can decrease as a result of increasing competition. Significantly negative and stable effects of competition only for the burned trees observed in the past decade implied that competition had a substantial impact over the long-term. Consequently, this finding supported the idea that tree ring data could be used to reconstruct the historic competition and explain variation in radial growth after fire-damage over the long term (Bergeron \& Archambault, 1993; Bergeron et al., 2001). For the first hypothesis, it was concluded from this study that relative strength between direct and indirect effects of fire varied on a temporal scale, as demonstrated by the changes in the growth pattern of Korean pine trees in the first 25 years following fire.

It was notable that both burned and control trees showed a dramatic response to changing climate conditions in 1922. Usually, trees benefit from fire through the increased availability of light, moisture, and nutrients (Swetnam et al., 1992). Control trees that were not affected by fire were also subject to fluctuating conditions affecting their growth. These effects may be explained by climate change or human disturbance. As the study sites located in Changbai Nature Reserve were protected and investigations indicated no harvest event occurred here, the influence from human disturbance can be excluded. Additionally, burned and control trees were more sensitive to climate change (Table 1). The study sites experienced warming since 1960 (Ren et al., 2005). During the years of increasing temperatures, the radial growth rates of the burned trees were higher than those of the control trees. This suggests that the differential growth pattern resulted from variability in the climatic response caused by the indirect effect of fire.

Correlation analyses revealed that radial growth of both burned and control trees were significantly negatively correlated with PG-T ${ }_{\max }$. A similar response of Korean pine trees to previous summer temperature was observed by Yu et al. (2011). High temperatures during the growing season prolong the duration of annual growth as a consequence of longer favorable growing conditions. The prolonged growing season consumes more stored nutrients, thereby reducing the availability of nutrition for tree growth in the following year, and thus retarding radial growth in the following year (Yu et al., 2005). Lower mean maximum temperature in the previous growing season $\left(\mathrm{PG}-\mathrm{T}_{\max }\right.$ ) in 1922 was also associated with a sharp increase in growth.

The minimum temperature in the current growing season (CG-T $\mathrm{T}_{\min }$ ) had a positive impact on burned trees, especially in February and May. However, radial growth of control trees had a significant negative correlation with $\mathrm{T}_{\min }$ in June. Higher mean minimum temperatures in the early growing season favor radial 
growth of conifers by increasing the photosynthetic rates of trees (Wu, 1990). Higher respiration during the growing season (Damesin et al., 2002) increases the demand for photosynthates at the expense of radial growth. Lower mean minimum temperature reduces tree respiration and increases retention of photosynthetic products for subsequent tree growth (Gao et al., 2011; Wang et al., 2011).

Precipitation during the current growing season (CG-P) and VPD in the previous growing season (PG-VPD) had significantly negative effects on the radial growth of burned pine trees, but positive effects on the growth of control trees. The positive relationship between CG-P and control tree growth was in agreement with the earlier report by Wang et al. (2013). The soil in our study is of volcanic origin and has a low water-holding capacity (Yu et al., 2005). Increased precipitation during the growing season thus increases soil moisture, which in turn stimulates radial growth in the current season (Wang et al., 2013). The negative effect of higher VPD on the soil water deficit appeared to be strengthened in this volcanic soil (Warren, 2008). Thus, greater VPD in the previous year retards the radial growth in the previous year. The positive effect of VPD on control trees could be explained by the high correlation between the VPD and temperature $(r=0.687)$. The higher VPD in September likely indicates that warmer conditions in early autumn postpone growth cessation. Thus, warmer conditions in early autumn could encourage growth, rather than limit it. Moreover, the longer growing season of the previous year conserves nutrients that are available to support radial growth of control trees in the following year. With respect to burned trees, radial growth was significantly negatively correlated with CG-P and PG-VPD. This runs counter to the traditional view that precipitation, particularly during the growing season, positively impacts growth of Korean pine trees (Shao \& Wu, 1997; Wang et al., 2013). Precipitation mainly impacts water table variation. Because their growth is strictly controlled by soil moisture, soil drainage and ventilation conditions, Korean pine trees favor soil conditions that are neither too dry nor too wet (Lious, 1955). As the average annual rainfall total in the study site is 707 $\mathrm{mm}$, with $74 \%$ falling during the growing season, it seemed likely that burned trees tended to grow more slowly under higher soil moisture levels. Rozas et al. (2011) found that oaks growing under high humidity had more reduced radial growth under higher competition. The burned trees were affected more severely by competition. This suggests that divergent precipitation effects between treatments could be partially connected to heterogeneous competition intensities.

Previous research suggested that the indirect effects of moderate negative climatic effects on sequoia growth (Mutch \& Swetnam, 1995) or impeded upslope establishment of forests in response to climatic warming are expected for to $21^{\text {st }}$ century (Colombaroli et al., 2010). In combination with the stable effect of PG-VPD on burned trees, our data suggested the indirect effect of fire makes Korean pine tree traits more sensitive to soil moisture over the long-term.

Additionally, the instability of the tree growth-climate relationship in the burned and control Korean pine trees during the late twentieth century (Fig. 5) suggested that as the temperature increased, it tended to disproportionately influence the growth of burned trees, while the control trees were more sensitive to precipitation. Liu et al. (1993) reported that Korean pine trees damaged by fire sprout more slowly and with shorter leaves but with higher levels of chlorophyll. Therefore, slight variation in temperature may have influenced photosynthesis; hence, physiological acclimation was likely responsible for the enhanced or diminished growth of burned trees (Wang et al., 2011). The study sites experienced climate warming but without any accompanying increase in precipitation (Fig. 1; Wang et al., 2002). The positive effect of CG-P on control trees was only significant at the beginning of the period of increasing temperatures. A similar response pattern was observed among Korean pines growing at high elevation in Changbai Mountain (Wang et al., 2013). Water availability during the relatively short growing season becomes a key factor for tree growth when ambient air temperatures are higher than the thermal boundary temperature (Carrer et al., 1998). The variability in growth of Korean pine trees following climate warming is likely a result of the response to changing competition for water (Skov et al., 2004). In the last decade there was no abrupt change in temperature. Therefore, that radial growth of burned trees, which was initially negatively influenced by competition, was no longer significantly different from that of the control trees.

This study demonstrated that the radial growth of Korean pine trees was negatively influenced by the direct effect of fire in the short term, specifically the first 5 years following fire, but both negatively and positively influenced by the indirect effect of fire over the long term. The indirect positive effect of fire outweighed the direct negative effects in the short period when trees recovered and were released from competition. Fire had both a negative and positive indirect effect on radial growth over the long term through changes to both climatic responses and competition. The present study may not provide a complete and definitive answer to the relative strength of the effects of varied climatic responses and changing competition on radial growth caused by fire. However, future investigations may build upon these findings to tease apart both the positive and negative effects of fire and ultimately advance our knowledge of the indirect effects of fire on radial growth. 


\section{Acknowledgements}

Authors thank the anonymous Referees and Associate Editor for the detailed revision and constructive comments that greatly improved manuscript. This research is supported by Program of Key Project of National Key Research and Development Plan (2017YFC0504003), National Natural Science Foundation of China (31600509; 31670643), and Beijing Excellent Talents Training Project (2013D009046000001).

\section{References}

Andreu L, Gutiérrez E, Macias M, Ribas M, Bosch O \& Camarero JJ (2007) Climate increases regional tree-growth variability in Iberian pine forests. Global Change Biology13: 804-815.

Arno SF \& Sneck KM (1977) A method for determining fire history in coniferous forests of the Mountain West. General Technical Report INT42. Department of Agriculture, Forest Service, Intermountain Forest and Range Experiment Station, Ogden, Utah.

Bakker JD (2005) A new, proportional method for reconstructing historical tree diameters. Canadian Journal of Forest Research 35: 2515-2520.

Bergeron Y \& Archambault S (1993) Decreasing frequency of forest fires in the southern boreal zone of Québec and its relation to global warming since the end of the 'Little Ice Age'. Holocene 3: 255-259.

Bergeron Y \& Harvey B (1997) Basing silviculture on natural ecosystem dynamics: an approach applied to the southern boreal mixed wood forest of Quebec. Forest Ecology and Management 92: 235-242.

Bergeron Y, Gauthier S, Kafka V, Lefort P \& Lesieur D (2001) Natural fire frequency for the eastern Canadian boreal forest: consequences for sustainable forestry. Canadian Journal of Forest Research 31: 384-391.

Bergeron Y, Harvey B, Leduc A \& Gauthier S (1999a) Forest management guidelines based on natural disturbance dynamics: stand- and forest-level considerations. Forestry Chronicle 75: 49-54.

Bergeron Y, Richard PJH, Carcaillet C, Gauthier S, Flannigan M \& Prairie Y (1999b) Variability in fire frequency and forest composition in Canada's southeastern boreal forest: a challenge for sustainable forest management. Conservation Ecology. 12. Article 6. http://www.consecol.org/vol2/ iss2/art6.

Biondi F \& Waikul K (2004) DENDROCLIM2002: A $\mathrm{C}++$ program for statistical calibration of cli- mate signals in tree-ring chronologies. Computer \& Geoscience 30: 303-311.

Briffa KR (1984) Tree-climate relationships and dendroclimatological reconstruction in the British Isles. Dissertation, University of East Anglia, Norwich, UK.

Briffa KR, Wigley TML \& Jones PD (1987) Standardization and the preparation of chronology: some contrasting approaches: Methods of dendrochronology I (ed. by L Kairiukstis, Z Bednarz \& E Feliksik) Proceedings of the Task Force Meeting on Methodology of Dendrochronology East/West Approaches, 2-6 June 1986, Krakow, Poland, pp. 69-86.

Carrer M, Anfodillo T, Urbinati C \& Carraro V (1998) High-altitude forest sensitivity to global warming: results from long-term and short-term analyses in the Eastern Italian Alps: The impacts of climate variability on forests (ed. by M Beniston \& JL Innes) Lecture notes in earth sciences, 74. Springer, Berlin Heidelberg, New York, pp. 171-189.

Certini G (2005) Effects of fire on properties of forest soils: a review. Oecologia 143: 1-10.

Clements FE (1910) The life history of lodgepole burn forests. U.S. Department of Agriculture, Forest Service, Bulletin.

Colombaroli D, Henne PD, Kaltenrieder P, Gobet E \& Tinner W (2010) Species responses to fire, climate and human impact at tree line in the Alps as evidenced by palaeo-environmental records and a dynamic simulation model. Journal of Ecology 98: 1346-1357.

Cook ER (1985) A time series analysis approach to tree-ring standardization. Ph.D. dissertation, Department of Geosciences, University of Arizona, Tucson.

Cook ER, Shiyatov S \& Mazepa V (1990) Estimation of the mean chronology: Methods of dendrochronology (ed. by ER Cook \& LA Kairiukstis) Kluwer Academic Publishers, Boston.

Damesin C, Ceschia E, Le Goff N, Ottorini JM \& Dufrêne E (2002) Stem and branch respiration of beech: from tree measurements to estimations at the stand level. New Phytologist 153: 159-172.

Daniels RF (1976) Simple competition indices and their correlation with annual loblolly pine tree growth. Forestry Sciences 22: 454-456.

Duncan RP (1989) An evaluation of errors in tree age estimates based on increment cores in kahikatea (Dacrycarpus dacrydioides). New Zealand Natural Sciences 16: 31-37.

Elliott KJ, Vose JM \& Clinton BD (2002)Growth of eastern white pine (Pinus strobus L.) related to forest floor consumption by prescribed fire in the southern Appalachians. Southern Journal of Applied Forestry 26: 18-25. 
Gadow K \& Hui GY (1999) Modelling forest development. Forestry Sciences 57.

Gao LS, Wang XM \& Zhao XH (2011) Response of Pinus koraiensis and Picea jezoensis var. komarovii to climate in the transition zone of Changbai Mountain, China. Chinese Journal of Plant Ecology 35: 27-34.

Liu L \& Ge J (2003) Effects of fire disturbance on the forest structure and succession in the natural broad-leaved/Korean pine forest. Journal of Forestry Research 14: 269-274.

Gonzalez-Rosales A \& Rodriguez-Trejo DA (2004) Effect of crown scorch on diameter growth of $\mathrm{Pi}$ nus hartwegii Lindl. at the Distrito Federal, Mexico. Agrociencia 38: 537-544.

González-Tagle MA, Schwendenmann L, Pérez JJ \& Schulz R (2008) Forest structure and woody plant species composition along a fire chronosequence in mixed pine-oak forest in the Sierra Madre Oriental, Northeast Mexico. Forest Ecology and Management 256: 161-167.

Grady LW \& Conrad JB (2001) Changing plant life of La Frontera: observations on vegetation in the U.S./Mexico borderlands. University of New Mexico Press, Albuquerque.

Grissino-Mayer HD (2001) Evaluating crossdating accuracy: A manual and tutorial for the computer program COFECHA. Tree Ring Research 57: 205-221.

Hoffmann WA (2002) Direct and indirect effects of fire on radial growth of cerrado savanna trees. Journal of Tropical Ecology 18: 137-142.

Hunt SM \& Simpson JA (1985) Effects of low intensity prescribed fire on the growth and nutrition of slash pine plantation. Australian Forest Research 15: 67-77.

Keeling EG \& Sala A (2012) Changing growth response to wildfire in old-growth ponderosa pine trees in montane forests of north central Idaho. Global Change Biology 18: 1117-1126.

Kummerow J \& Lantz RK (1983) Effect of fire on fine root density in red shank (Adenostoma sparsifolium Torr.) chaparral. Plant and Soil 70: 347-352.

Latham P \& Tappeiner J (2002) Response of oldgrowth conifers to reduction in stand density in western Oregon forests. Tree Physiology 22: 137146.

Liu H (1993) Influence of fire on korean pine and scots pine trees in plantation. Journal of Northeast Forestry University 4: 11-17.

Lious T (1955) Illustrated flora of ligneous plants of Northeast China. Beijing Science Press.

McInnis LM, Oswald BP, Williams HM, Farrish KW \& Unger DR (2004) Growth response of Pinus tae$d a$ L. to herbicide, prescribed fire, and fertilizer. Forest Ecology and Management 199: 231-242.
Mutch LS \& Swetnam TW (1995) Effects of fire severity and climate on ring-width growth of giant sequoia after burning. Proceedings: Symposium on Fire in Wilderness and Park Management, Forest Service General Technical Report Intermountain 320: 241-246.

Nowacki GJ \& Abrams MD (1997) Radial-growth averaging criteria for reconstructing disturbance histories from presettlement-origin oaks. Ecological Monographs 67: 225-249.

Pearson HA, Davis JR \& Schubert GH (1972) Effects of wildfire on timber and forage production in Arizona. Journal of Range Management 25: 250-253.

Peterson DL \& Arbaugh MJ (1989) Estimating postfire survival of Douglas-fir in the Cascade Range. Canadian Journal of Forest Research 19: 530-533.

Peterson DL, Arbaugh MJ, Pollock GH \& Robinson LJ (1991) Postfire growth of Pseudotsuga menziesii and Pinus contorta in Northern Rocky Mountains, USA. International Journal of Wildland Fire 1: 63-71.

Py C, Bauer J, Weisberg PJ \& Biondi F (2006) Radial growth responses of singleleaf pinyon (Pinus monophylla) to wildfire. Dendrochronologia 24: 39-46.

Ren GY, Guo J, Xu MZ, Chu ZY, Zhang L, Zou XK, Li QX \& Liu XN (2005) Climate changes of China's mainland over the past half century. Acta Meteorologica Sinica 63: 942-956.

Riegel GM, Miller RF \& Krueger WC (1992) Competition for resources between understory vegetation and overstory Pinus ponderosa in Northeastern Oregon. Ecological Applications 2: 71-85.

Rozas V , Pérez-de-Lis G , García-González I \& Arévalo JR (2011) Contrasting effects of wildfire and climate on radial growth of Pinus canariensis on windward and leeward slopes on Tenerife, Canary Islands. Trees 25: 895-905.

Ryan KC \& Frandsen WH (1991) Basal injury from smoldering fires in mature Pinus ponderosa Laws. International Journal of Wildland Fire 1: 107-118.

Ryan KC \& Reinhardt ED (1988) Predicting postfire mortality of seven western conifers. Canadian Journal of Forest Research 18: 1291-1297.

Shao XM \& Wu XD (1997) Reconstruction of climate change on Changbai Mountain, northeast China using tree-ring data. Quaternary Sciences 7: 76-85.

Skov KR, Kolb TE \& Wallin KF (2004) Tree size and drought affect ponderosa pine physiological response to thinning and burning treatments. Forestry Science 50: 81-91.

Souza AF (2007) Ecological interpretation of multiple population size structures in trees: the case of Araucaria angustifolia in South America. Austral Ecology 32: 524-533. 
Stokes MA \& Smiley TL (1968) An introduction to tree-ring dating. University of Chicago Press, Chicago.

Stone R (2010) Is China's riskiest volcano stirring or merely biding its time? Science 329: 498-499.

Swetnam TW, Baisan CH, Caprio AC, Touchan R \& Brown PM (1992) Tree-ring reconstruction of giant sequoia fire regimes. Final Report to Sequoia and Kings Canyon and Yosemite National Parks, Cooperative Agreement DOI 8018-1-0002. Laboratory of Tree-Ring Research, University of Arizona, Tucson.

Valor T, Piqué M, López \& González-Olabarria JR (2013) Influence of tree size, reduced competition, and climate on the growth response of Pinus nigra Arn. salzmannii after fire. Annuals of Forest Science 70: 503-513.

Van Sickle FS \& Hickman RD (1959) The effect of understory competition on the growth rate of ponderosa pine in northcentral Oregon. Journal of Forestry 57: 852-853.

Wang H, Shao XM, Fang XQ, Yin ZY, Chen L, Zhao DS \& Wu SH (2011) Responses of Pinus koraiensis tree ring cell scale parameters to climate elements in Changbai Mountain. Chinese Journal of Applied Ecology 22: 2643-2652.

Wang H, Shao XM, Jiang Y, Fang XQ, Wu SL (2013) The impacts of climate change on the radial growth of Pinus koraiensis along elevations of Changbai Mountain in northeastern China. Forest Ecology and Management 289: 333-340.

Wang SW, Cai JN, Zhu JH \& Gong DY (2002) Studies on climate change in China. Climatic and Environmental Research 7: 137-145.

Wang XC \& Zhao YF (2011) Growth release determination and interpretation of Korean pine and Koyama spruce in Shengshan National Nature Re- serve Heilongjiang Province China. Acta Ecologica Sinica 31: 1230-1239.

Wang XG, Li XZ, Kong FH, Li Y, Shi B \& Gao Z (2003) Model of vegetation restoration under natural regeneration and human interference in the burned area of northern Daxin'anling. Chinese Journal of Ecology 22: 30-34.

Wang YT, Kan ZG \& Chen Y (2007) Dynamics of biomass and productivity in the natural restoration progress of the Pinus densata burned areas in western Sichuan province. Forestry Science and Technology 32: 82-94.

Warren CR (2008) Soil water deficits decrease the internal conductance to $\mathrm{CO} 2$ transfer but atmospheric water deficits do not. Journal of Experimental Botany 59: 327-334.

Wigley TML, Briffa KR \& Jones PD (1984) On the average value of correlated time series, with applications in dendroclimatology and hydrometeorology. Journal of Climate and Applied Meteorology 23: 201-213.

Wooldridge DD \& Weaver H (1965) Some effects of thinning a ponderosa pine thicket with a prescribed fire, II. Journal of Forestry 63: 92-95.

Wu XD (1990) Tree-ring and climate change. Meteorology Publisher, Beijing.

Yang SC, Liu XT, Cao HB \& Guo B (1998) Vegetation change on burn blank in Daxing'anling forest areas. Journal of Northeast Forestry University 26: 19-23.

Yu DP, Gu HY, Wang JD, Wang QL\& Dai LM (2005) Relationships of climate change and tree ring of Betula ermanii tree line forest in Changbai Mountain. Journal of Forestry Research 16: 187-192.

Yu D, Wang Q, Wang Y, Zhou W, Ding H, Fang X, Jiang S \& Dai L (2011) Climatic effects on radial growth of major tree species on Changbai Mountain. Annals of Forest Science 68: 921-933. 